\title{
РОЛЬ А.І. КИРИМЛИ У РОЗВИТКУ РУХУ КРИМСЬКОЇ ДІАСПОРИ ТУРЕЧЧИНИ (КІНЕЦЬ 1980-х - ПОЧАТОК 2000-х рp.)
}

Анотація: Стаття присвячена діяльності видатного діяча світової та турецької діаспор киримли, державного та політичного діяча Туреччини, Амєта Іхсана Киримли (1920-2011) наприкінщі 20 сторіччя щодо об'є днання кримської діаспори Туреччини, інституалізащї діаспорного руху, створення умов стосовно ефективної підтримки прощесу репатріації народу киримли з місць колишнього заслання на історичну Батьківщину - Крим з боку діаспорних організацій Туреччини тощо. Оцінюються його роль і внесок у процеси відновлення прав і свобод киримли, відродження їхніх культури, мови та освіти. Також досліджуються маловідомі в Украӥні історичні факти щодо співробітнищтва А.І. Киримли з представниками світової української діаспори та його діяльності стосовно розвитку плідних відносин між незалежною Україною та Турецькою Республікою.

Ключові слова: Амєт Іхсан Киримли, кримська діаспора, киримли, Крим, Туреччина, реnampiauis

Описуючи діяльність кримської діаспори в історії Туреччини кінця 2000-х рр., неможливо залишити поза увагою роль постаті Амєта Іхсана Киримли, який кардинально вплинув на розвиток організованого діаспорного руху киримли ${ }^{1}$, ставши стрижнем, навколо якого організаційно сформувалася сучасна кримська діаспора Туреччини.

На жаль, питання розвитку організованого життя кримської діаспори Туреччини, її внеску у процес репатріації народу киримли до Криму, відродженні його культури, освіти, духовності, зокрема, ролі та місця у цих процесах А.І. Киримли, й досі залишається недослідженим українськими істориками. Це питання висвітлювалося доволі фрагментарно, у контексті загальних досліджень національно-визвольної боротьби народу киримли за свої права. Між тим, підтримка повернення кримців з місць колишнього заслання на історичну Батьківщину з боку турецької діаспори, була різносторонньою й охоплювала десятки тисяч членів кримських громад Туреччини.

Тому актуальність теми визначається необхідністю системного дослідження ролі кримської діаспори Туреччини у процесі повернення народу киримли на історичну Батьківщину, осмислення її внеску та впливу на відродження культури киримли, захисту їхніх прав і свобод, а також внеску видатного державного та політичного діяча Туреччини A.I. Киримли. Відносини України з Турецькою Республікою, як стратегічних партнерів, об'єктивно зумовлюють потребу наукового осмислення участі у них кримців Туреччини, їхнього впливу на країну перебування та зв’язків з історичною Батьківщиною.

\footnotetext{
* Аблятіфов Рустем Мамут оглу - магістр державного управління, здобувач ступеня доктора філософії, історичний факультет Львівського національного університету імені Івана Франка

ORCID: https://orcid.org/0000-0002-3368-7203; e-mail: abu-bakr@ukr.net

${ }^{1}$ Q lrtmll - «киримли», етнонім-самоназва корінного народу Криму, відомого також як «кримські татари».
} 
Серед зарубіжних і вітчизняних дослідників, які досліджували ці питання можна виділити А.М. Арабаджи르, Б.Г. Вільямса ${ }^{3}$, М. Губогло ${ }^{4}$, Е. Кангієву ${ }^{5}$, Х. Киримли ${ }^{6}$, Е. Оллуорта ${ }^{7}$, П. Реддуея ${ }^{8}$, Е. Сєйдамєтова ${ }^{9}$, М. Улькюсала ${ }^{10}$, А. Фішера ${ }^{11}$, С. Червонну ${ }^{12}$ тощо.

Так, якщо М.Н. Губогло та С.М. Червонна ретельно досліджуючи національний рух киримли за право повернення до Криму у колишньому СРСР, фрагментарно згадували про контакти активістів руху з представниками кримської діаспори Туреччини, то А.М. Арабаджи, у власному дослідженні загальної діяльності діаспорних організацій, так само не акцентував свою увагу на ролі та впливі діаспори Туреччини на процес репатріації народу киримли на історичну Батьківщину. Е. Кангієва дослідила один з аспектів діяльності кримської діаспори, а саме, її періодичні видання, Е. Сєйдамєтов, натомість, описав діяльність щодо підтримки руху репатріації киримли, але кримської громади США, опосередковано згадавши про ї̈ зв'язки з громадою Туреччини. Праці М. Улькюсала, Х. Киримли та А. Фішера розглядають історичні події, що відбувалися у діаспорних громадах до початку 1980-х рр., себто, до початку масового повернення репатріантів до Криму. Крім того, Х. Киримли описує у власних дослідженнях етапи еміграції кримців та їхнє облаштування у Туреччині. Б.Г. Вільямс, Е. Оллуорт, П. Реддуей досліджували загальну історію народу киримли, процес його повернення на історичну Батьківщину, так само фрагментарно торкаючись діяльності кримської діаспори Туреччини. Тим більше, в усіх цих працях можна знайти лише окремі згадки про постать А.І. Киримли, але не встановлення його ролі та внеску у процес репатріації киримли, як лідера кримської громади Туреччини, наприкінці 1980-х - початку 2000-х рр.

Амєт Іхсан Киримли (Ahmet İhsan Kirtml) народився 23 квітня 1920 р. у м. Баликесір, Туреччина. Прадід А.І. Киримли, ісламський вчений Улема-йі Ізам Мєшайіх-і Кірам Аксєйід Мємєт-ефенді з Багчасараю, після Кримської війни, як інші його

\footnotetext{
${ }^{2}$ Arabacı H.M. Türk Tarihi ve Kültürü Açısından Türkiye'de Bulunan Kırım Dernek ve Vakıflarının Önemi. Tarih Anabilim Dalı Doktora Tezi. İstanbul Üniversitesi Sosyal Bilimler Enstitüsü, İstanbul, Türkiye, 2006. 125 s. URL: http://nek.istanbul.edu.tr:4444/ekos/TEZ/41902.pdf

${ }^{3}$ Williams B.G. The Crimean Tatars: the diaspora experience and forging a nation. Leiden; Boston; Köln: Brill, 2001. $520 \mathrm{p}$.

${ }^{4}$ Губогло М.Н., Червоннал С.М. Крымскотатарское национальное движение. Т. 1. История. Проблемы. Перспективы. Москва, 1992. 331 с.

${ }^{5}$ Кангієва Е.M. Вивчення історії та етнографії Криму в тюркомовній періодиці кримськотатарської діаспори (1888-1991 рр.): автореф. дис... канд. іст. наук. Дніпропетровськ, 2008. 20 с.

${ }^{6}$ Kırımlı H. Türkiye'deki Kırım Tatar ve Nogay Köy Yerleşimleri. İstanbul: Tarih Vakfı Yurt Yayınları, 2012. 678 s.

${ }^{7}$ The Tatars of Crimea Return to the Homeland / ed. by E. Allworth. Duke University Press; Durham and London, 1998. $400 \mathrm{p}$.

${ }^{8}$ Reddaway P. The Crimean Tatar drive for repatriation. In: Tatars of Crimea. Return to the Homeland / Ed. E. Allwourth. Duke University Press; Durham and London, 1998. P. 226-236.

${ }^{9}$ Сейдаметов Е.X. Рух солідарності кримськотатарської діаспори у США з боротьбою співвітчизників за повернення на історичну батьківщину (1960-ті - початок 2000-х років): автореф. дис... канд. іст. наук. Одеса, 2007. $21 \mathrm{c}$.

${ }^{10}$ Ülküsal M. Kırım yolunda bir ömür. Hatıralar. Ankara: Kırım Türkleri Kültür ve Yardımlaşma Derneği Genel Merkezi, 1999. $424 \mathrm{~s}$.

${ }^{11}$ Fisher A. The Crimean Tatars, the USSR and Turkey. In: Soviet Asian Etnic Frontiers / ed. William McCagg and Brian Silver. New York, Pergamon Press, 1979. P. 1-24.

${ }^{12}$ Губогло М.Н., Червоннал С.M. Op. cit.
} 
співвітчизники, відправив свою родину до Aq topraq ${ }^{13}$. Сам він залишився у Криму. Своїй родині Аксєйід Мємєт-ефенді дав трохи грошей і Святий Коран, на початку якого написав їм такі слова: «Я залишатимусь тут, мої плоть та кістки стануть землею, на ній ростимуть трави, і на їхній запах прийдуть сюди мої онуки». Родина знайшла притулок у м. Баликесір, де оселилася у «Кримському кварталі», побудованому урядом султана Абдульмєджида І для переселенців.

У 1947 р. А.І. Киримли закінчив медичний факультет Істанбульського університету. Його громадська діяльність розпочалася саме під час навчання: він був обраний до керівних органів студентської спілки університету та спілки студентів Баликесіра. Після чого, у 1949-1957 pр. проходив спеціалізації в області педіатрії у Великій Британії та США ${ }^{14}$. Як можна бачити, Киримли прагнув вдосконалити себе як лікар, перейняти передовий досвід у медицині. У Великій Британії, крім того, він пройшов гарну школу політичної діяльності як член ради Федерації турецьких студентів. Саме тут, в Англії, А.І. Киримли дізнався приголомшуючу новину про Депортацію народу киримли у 1944 р. Тоді він вирішив активно боротися за відновлення історичної справедливості по відношенню до своїх співвітчизників. 3 того часу справа допомоги народу киримли стало ділом його життя ${ }^{15}$. В Америці він також не залишив активну громадську діяльність: заснував та очолив Асоціацію турецьких студентів США та долучився до Американської асоціації кримських тюрків (АСКТ). Згодом, АСКТ надасть А.І. Киримли звання «Почесного» голови» за великий внесок в її розбудову ${ }^{16}$.

Протягом 1950-1957 рр. Киримли активно працював, аби у США дізналися про долю депортованого радянським режимом народу киримли. Для цього він організував там кілька конференцій. Американський період життя Киримли мав величезне значення для його подальшої долі. Саме тут він познайомився зі славетними борцями за незалежність України - подружжям Ярослава та Ярослави Стецько ${ }^{17}$. Їхня дружба тривала усе життя. У ті роки, спілкуючись з представниками української діаспори, А.І. Киримли дізнався про Україну. Киримли розповідав про кумедний випадок, що трапився у ті роки, коли вони співпрацювали у рамках Антибільшовицького блоку народів (АБН), і мав пожартувати, аби розрядити ситуацію: «На одному із засідань [АБН] у Мюнхені йшла мова про кримців, і головувала там Слава Стецько. Чи то вона, чи то хтось інший сказав, що «ці татари одні розбійники, вони нападали на Україну, забирали гарних жінок, та відвозили до Криму». Киримал піднімає руку, та каже: «Так, було таке. В усьому винні самі українці». Усі

\footnotetext{
${ }^{13}$ «Світла земля» - символічна назва Туреччини серед народу киримли у середньовіччі, як земля, що знаходиться під управлінням Халіфа усіх мусульман.

${ }^{14}$ Aytar N. Meşhurlarımız - Dr. Ahmed İhsan Kırımlı // Kırım Bülten. 2009. Sayı 64. S. 4.

${ }^{15}$ Ахмет Ихсан Кырымлы. URL: http://medeniye.org/node/815

${ }^{16}$ Aytar N. Op. cit.

${ }^{17}$ Ярослав Семенович Стецько (1912 року - 1986) - український політичний і військовий діяч, активний діяч ОУН. 31941 р. - перший заступник провідника ОУН-Б. У 1942-1944 рр. перебував у німецькому концтаборі Заксенгаузен. Після звільнення керував Антибільшовицьким блоком народів, був головою Проводу ОУН-Б.

Ярослава (Слава) Йосипівна Стецько (уроджена Ганна Йосипівна Музика; 1920-2003) - українська політична діячка, журналістка, співорганізатор Червоного Хреста УПА, жіночої мережі і юнацтва ОУН, Антибільшовицького блоку народів (АБН). Голова ОУН(б) (1991-2001). Перший лідер партії Конгрес українських націоналістів. Депутат Верховної Ради України 2, 3 і 4-го скликань.
} 
здивовано переглядаються. А він продовжує: «Ви подивіться на пані Стецько - у свої 50 років вона така красуня! А уявіть, що їй 18 років, ну який чоловік не вкраде ії? Крім того, ви покажіть хоч одну українську жінку, яка з Криму попросилася б назад?»" ${ }^{18}$.

Після повернення із США, Киримли мав приватну лікарську практику у рідному місті, одночасно не полишаючи активну громадсько-політичну діяльність. Він був членом керівних органів міського осередку Демократичної партії та кількох громадських організацій. У 1961 р. А.І. Киримли обирають депутатом Великих Національних Зборів Туреччини від м. Баликесір від Adalet Partisi (Партії Справедливості, ПС). На першому зїзді ПС, що відбувся у 1962 р., він був обраний членом Генеральної виконавчої ради та виконував ці обов'язки до 1976 р. Протягом 6 років він працював заступником голови партіїі. Протягом 4 скликань, до 1977 р. Киримли був депутатом парламенту і на різних міжнародних форумах постійно намагався привернути увагу громадськості до проблеми народу киримли щодо відновлення права повернутися на історичну Батьківщину. Як депутат парламенту, Киримли відвідував СРСР і мав зустріч з тодішнім керівником Радянського Союзу М. Хрущевим. Й саме він став першим іноземним політиком, якому вдалося у 1980-ті рр. зустрітися з радянським дисидентом Мустафою Джемілєвим ${ }^{20}$.

Послужний список А.І. Киримли, як політичного та державного діяча Туреччини, вкрай великий: у 1973-74 pp. він обіймав посаду міністра туризму та промоції, одночасно був спікером і головою комісії охорони здоров’я, секретарем комісії парламенту з питань оборони. У складі урядових делегацій взяв участь у багатьох державних візитах.

Тобто, у 1987 р., коли А.І. Киримли був обраний головою Товариства культури, фольклору та взаємодопомоги кримських тюрків Анкари, можна впевнено казати, що він входив до політичної еліти країни. До того ж, увесь його життєвий шлях свідчив про його активну позицію та надзвичайні організаторські здібності. Він завжди підкреслював, що «пишається тим, що є кримським татарином» ${ }^{21}$. Саме тому, свій авторитет серед політичного істеблішменту Туреччини, власні знання та навички, Киримли використовував на користь своїх співвітчизників, як у діаспорі, так і на Батьківщині. Слід зазначити, що перші товариства киримли створювались як організації, що займалися культурою та фольклором. Саме таким товариством також було об’єднання в Анкарі, яке утворилося у 1955 р. Потрібно відмити, що на той час діяльність кримських товариств здебільшого обмежувалася справлянням вечірок на кшталт «Кримських ночей» чи «Днів чебурека» 22.

Тому, як людина 3 великим державним досвідом, А.І. Киримли, розумів, аби акумулювати зусилля кримської діаспори задля допомоги народу киримли, потрібно карди-

\footnotetext{
${ }^{18}$ Корниенко Я. «Мустафа Джемилев: «Наша позиция по Крыму такая: пусть берут все, пусть подавятся. Все равно потом заберем». URL: https://reinvent.platfor.ma/mustafa-dzhemilev/

${ }^{19}$ Aytar N. Op. cit.

${ }^{20}$ B Крыму широко отметят 85-летие главы крымскотатарской диаспоры Турции Ахмета Кырымлы. URL: http://old.qha.com.ua/ru/obschestvo/v-krimu-shiroko-otmetyat-85letie-glavi-krimskotatarskoi-diaspori-turtsiiahmeta-kirimli/1272/

${ }^{21}$ Бекирова Г. «Наш дорогой Ахмед-эмдже». URL: https://ru.krymr.com/a/26976109.html

${ }^{22}$ Toprak F. Perception of Homeland Among Crimean Tatar Diaspor Living in Turkey as Reflected on the Diaspora Journal Emel. Thesis for a Master of Social Science. Middle East Technical University, Ankara, 2013. P. 172-175. URL: http://ansamblperegrinus.pl/uploads/artykuly/perception_of_homeland_among_crimean_tatar_diaspora_ living_in_turkey_feyza_toprak.pdf
} 
нально змінити діаспорний рух. У першу чергу, об’єднавши розрізнені громади, перебудувати товариства на загальнонаціональний рух. Результатом 3 років перемовин, роз'яснень, стала зустріч кількох організацій 26 грудня 1990 р., на якій було досягнуто домовленості про об'єднання 7 осередків у Товариство культури та взаємодопомоги кримських тюрків Туреччини (ТКВКТ) із Genel Merkezi (Загальним центром) в Анкарі. Загалом, за керівництва А.І. Киримли 31990 р. до 2011 р. число організацій, що об'єдналися навкруги Анкари, досягло 2523. Одночасно, лідер кримської діаспори був головою Федерації тюрків Болгарії, Азербайджану та Криму. Крім великої парасолькової організації, у різних містах країни функціонують ще 13 незалежних товариств i фондів киримли. А.М. Арабаджи впевнений, що попри розбіжності між різними організаціями, що властиво для демократичного суспільства, уся діаспора спромоглася об’єднатися навколо важливої для народу мети або у критичній ситуації ${ }^{24}$.

Киримли також зіграв важливу роль в отриманні від Уряду Туреччини статусу «організації, що діє заради суспільного блага» у 1992 р., що дозволило отримати урядове фінансування діяльності ТКВКТ ${ }^{25}$. Цей поважний статус, який, зокрема, свідчить про політичну вагу кримської діаспори у Туреччині, дав потужний поштовх розвитку діаспорного руху. Це також важливе досягнення для розвитку організованого діаспорного руху, яке вивело організацію на якісно новий рівень. Загальний центр ТКВКТ, таким чином, отримав можливість підтримувати свої осередки по країні, розподіляючи ресурси між невеликими чи фінансово слабкими філіями ${ }^{26}$. Сьогоднішній лідер ТКВКТ Мюкрємін Шаін, наголошуючи на його організаційні здібності, казав про Киримли: «Якщо у нас були б такі самі можливості та повноваження, ми не змогли б так само інституційно вибудувати кримське товариство до такого рівня, не змогли б досягнути таких успіхів як він. ...у тих умовах, ми не змогли би досягти успіхів у фінансових справах» ${ }^{27}$.

Саме ці фактори: об'єднання зусиль кількох десятків громад та урядова підтримка, призвели до поширення національної ідеї серед представників кримської діаспори Туреччини, багатократно зміцнили національні почуття кримців, викликали відчуття причетності діаспори до долі власного народу, піднесли політичну вагу кримської діаспори серед турецького суспільства, що дозволило ефективно лобіювати кримське питання серед турецького політикуму, що, урешті-решт, надало кумулятивного ефекту діям діаспори щодо надання допомоги народу киримли.

Киримли, як людина, надзвичайно переймався долею своїх співвітчизників і намагався зробити усе можливе, щоб посприяти поверненню та допомогти облаштуванню репатріантів-киримли на історичній Батьківщині. Він намагався, щоб процес допомоги не був

\footnotetext{
${ }^{23}$ Teşkilat. URL: http://www.kirimdernegi.org.tr/dernek/teskilat

${ }^{24}$ Arabacı H.M. Türk Tarihi ve Kültürü Açısından Türkiye'de Bulunan Kırım Dernek ve Vakıflarının Önemi. Tarih Anabilim Dalı Doktora Tezi. İstanbul Üniversitesi Sosyal Bilimler Enstitüsü, İstanbul, Türkiye, 2006. s. 125. URL: http://nek.istanbul.edu.tr:4444/ekos/TEZ/41902.pdf

${ }^{25}$ Tariçhe. URL: http://www.kirimdernegi.org.tr/dernek/tarihce

${ }^{26}$ Так, наприклад, рішенням ЗЦ ТКВКТ від 14.12 .02 р. вирішено сплатити витрати філій ТКВКТ на організацію зібрань, або рішенням від 27.03 .03 р. осередку у Коджаелі на потреби виділено 500 млн. лір. Архів ТКВКТ. Книга рішень за 2002 р. Книга рішень за 2003 р.

${ }^{27}$ Merhum Genel Başkanımız Dr. Ahmed İhsan Kırımlı Dualarla Anıldı URL: http://www.kirimdernegi.org.tr/haberler/1086-merhum-genel-baskanimiz-dr-ahmed-ihsan-kirimli-dualarla-anildi
} 
хаотичним, а набув системного порядку. Він волів, щоби товариства діяли за планом і дотримувалися певної стратегії у наданні допомоги Криму. Як фаховий лікар, А.І. Киримли переживав за здоров'я репатріантів, оскільки бачив, що часто-густо вони обмежені у доступі до медичних послуг у Криму. Зокрема, за його ініціативою серед кримської діаспори Туреччини була розпочата кампанія зі збору коштів «Побудуємо лікарню для Криму!», аби створити сучасну лікарню, куди могли би звертатися репатріанти з усього Криму ${ }^{28}$.

Так само системно, він організовував і діаспорний рух всередині Туреччини. Активісти ТКВКТ підкреслюють його вирішальну роль у створенні загальнотурецького діаспорного руху, розбудові сучасної структури товариства, у його інституційному становленні. Вони переконані, що завдяки об'єднанню окремих кримських громад у потужну організацію, вдалося вибудувати ефективну систему допомоги власному народові у поверненні до Криму, відродженню національної культури ${ }^{29}$. Заслуга Киримли, у першу чергу, полягає у тому, що він змінив вектор діяльності кримських товариств: не на задоволення власних потреб і бажань, як-от, вивчення фольклору чи проведення розважальних заходів, а на працю заради допомоги власному народові та історичній Батьківщині.

Загальний центр ТКВКТ наполегливо працював над підвищенням авторитету національних представницьких органів киримли - Курултаю та Меджлісу кримськотатарського народу у Туреччині. 5 лютого 1992 р., себто, через два дні після визнання Туреччиною незалежності України, новообраний Голова Міллій Меджлісу М. Джемілєв прибув 3 візитом до цієї країни ${ }^{30}$. Це був не просто перший візит М. Джемілєва в якості лідера Меджлісу, а взагалі перше у його житті відвідування Туреччини. Тому візит голови Меджлісу, ретельно організований ТКВКТ й особисто А.І. Киримли, мав велике історичне та символічне значення для кримської діаспори.

Громада киримли зустріла М. Джемілєва, з великим піднесенням, як національного героя: зустріти його на летовищі зібралися тисячі людей, кавалькада, що супроводжувала голову Меджлісу, розтягнулася більш ніж на п'ять кілометрів, його вітали з прибуттям на усьому шляху від Істанбулу до Анкари ${ }^{31}$. Турецька Республіка також приймала М. Джемілєва на найвищому державному рівні. Серед вищих посадових осіб і провідних політиків країни, які зустрічалися з ним, були: президент Тургут Озал, голова парламенту Хюсаметтін Джіндорук, прем'єр-міністр Сулейман Демірель, міністри, лідери партій, губернатори провінцій і міські голови. Варто зауважити, що усі зустрічі були не просто протокольними, а були надзвичайно емоційно забарвленими, проходили у вкрай доброзичливій і щирій атмосфері. За час перебування у Туреччині Голова Меджлісу взяв участь у конференціях у кількох університетах, мав численні зустрічі з громадськістю, інтелігенцією, дав численні прес-конференції й інтервю турецьким медіа ${ }^{32} .3$ того часу, лідерів Меджлісу приймають у Туреччині на вищому державному рівні, а М. Джемілєва називають не інакше, як «Qırımoğlu», себто, «син Криму».

\footnotetext{
${ }^{28}$ Özşeker B. «Kırım Türkleri’nin sağlık sorunları» // Bağçesaray. 1994. Sayı 2. S. 2.

${ }^{29}$ Інтерв'ю з Тунджером Калкаєм (Tuncer Kalkay) записано 29.11.2018 р. у м. Анкара; інтерв'ю з Намиком Кємалом Баяром (Namık Kemal Bayar) записане 20.12.2018 р. у м. Анкара; інтерв'ю з Оя Деніз Чонгар-Шаін (Оуа Deniz Çonğar-Sahin) записане 02.01.2019 р. у м. Анкара.

${ }^{30}$ Karatay Z. Kırım Tatar Meclisi Başkanı ve Meclis heyetinin Türkiye ziyareti // Emel. 1992. № 188. S. 1.

${ }^{31}$ Інтерв'ю із Зафєром Каратаєм (Zafer Karatay) записане 30.01.2019 р. у м. Істанбул.

${ }^{32}$ Karatay Z. Op. cit. S. 1-32.
} 
ТКВКТ послідовно працювало з урядовими органами, лобіюючи питання допомоги своїм співвітчизникам у Криму. Так, у звітах про діяльність ТКВКТ можна знайти згадки про регулярні контакти його представників з різними міністрами. Заради підтримки Днів кримськотатарської культури у Києві, ТКВКТ провело перемовини з МЗС Туреччини у 2003 р. Також, згадується і про контакти з Радою вищої освіти задля сприяння абітурієнтам з Криму ${ }^{33}$. Активісти наголошували, що ухвалення жодного рішення влади Туреччини стосовно інтересів народу киримли на будь-якому рівні не обійшлося без їхньої участі: від muhtar (старости) кварталу чи села до глави держави ${ }^{34}$.

Слід відзначити, що хоча національний рух киримли під час боротьби за повернення до Криму у СРСР апелював до міжнародної спільноти, найбільшу надію кримці покладали на Aq topraq. Історична пам'ять, що зберігалася серед народу киримли, змушувала його чекати підтримку з боку їхніх найближчих родичів. Навіть попри те, що це очікування часто-густо були перевищеними, надія на підтримку турецького народу ніколи не полишала киримли.

Проте, з середини 1990-х рр. певна ейфорія від очікувань на турецьку допомогу потроху стала розвіюватися, оскільки фінансові ресурси Туреччини були обмежені та їі уряд виділяв кошти лише на деякі культурні програми репатріантів-киримли.

Це підтверджує й Ф.Т. Айдин: «У регіоні Чорного моря, у 2000-х рр., у той час, коли двосторонні відносини Туреччини з Україною, Грузією та Азербайджаном плідно розвивалися, турецька зовнішня політика, в цілому, була не дуже активною. В її зовнішньополітичному дискурсі навіть боснійці і палестинці знайшли більше відображення, ніж кримські татари, чеченці та черкеси - північні тюркські та мусульманські брати. Зовнішня політика Туреччини у Чорному морі здебільшого формувалася з огляду на традиційний інтерес до забезпечення морської безпеки та суверенітету над протоками» ${ }^{35}$.

Тому, в умовах інституційної слабкості молодої української держави, неоднозначного ставлення уряду України, як до процесу репатріації, так і до народу киримли, та часто-густо відверто ворожого ставлення до репатріантів-киримли пострадянської та російськомовної, за своєю сутністю, влади Кримського півострову на усіх рівнях, відсутності фінансових і матеріальних ресурсів народу киримли у цілому, важливість допомоги з боку кримської діаспори Туреччини ставала критично важливою для процесу становлення національних інститутів киримли, відродження їхньої культури та духовності.

Причому, лідер кримської діаспори думав стратегічно: він був впевнений, що народ у Криму повинен мати усі можливі атрибути сучасної нації, щоб розвиватися незалежно від бажань чи можливостей влади чи суспільств, що його оточують. Тому, метою діаспори було створення банку, видавництва, лікарні, засобів масової інформації, освітніх і культурних закладів, об'єктів культу тощо 36.3 одного боку, ця мета була обумовлена тим, що діаспора

\footnotetext{
${ }^{33}$ Arabact H.M. Op. cit. S. 97-98.

${ }^{34}$ Вказ. інтерв'ю з Т. Калкаєм; вказ. інтерв'ю з Н.К. Баяром.

${ }^{35}$ Айдин Ф.T. Чорноморська політика Туреччини: Балансування чи «Російська рулетка»? // Чорноморська безпека. 2017. № 1 (29). С. 57.

${ }^{36}$ Aydin F.T. Comparative Cases in Long-Distance Nationalism: Explaining Émigré, Exile, Diaspora and Transnational Movements of the Crimean Tatars. Thesis for a Doctor of Philosophy in Political Science, University of Toronto, Toronto, $\quad$ Canada. $2012 . \quad$ P. $351 . \quad$ URL:
} https://tspace.library.utoronto.ca/bitstream/1807/67253/1/Aydin_Filiz_T_201211_PhD_thesis.pdf 
була занепокоєна нехтуванням прав киримли, значним обмеженням їхнього доступу до ресурсів і державних послуг у Криму, з іншого боку, діаспора воліла діяти інституційно, тобто, закласти певні підвалини задля відновлення державності народу у майбутньому.

За свідченням члена правління ТКВКТ Н.К. Баяра, згідно із записами у книгах рішень ТКВКТ, з кінця 1990-х рр. вони змогли акумулювати та спрямувати допомоги до Криму на суму більше ніж 5 млн. доларів США ${ }^{37}$.

Іншою сферою діяльності кримської діаспори було сприяння розвиткові плідних турецько-українських відносин. Киримли Туреччини уповні намагалися виконати роль містка між країнами, що ім відводили політики й експерти. Останні підкреслюють, що «до теперішнього часу організації кримців були лідерами щодо дружби та тісних зв'язків між Туреччиною та Україною» ${ }^{38}$. У рамках цієї діяльності, ТКВКТ організовувало в обох країнах семінари та конференції щодо розвитку економіки Криму та залучення інвестицій ${ }^{39}$, започаткування бізнесу на півострові, сприяли встановлення побратимських відносин між українськими та турецькими містами ${ }^{40} .3$ моменту початку функціонування українських дипломатичних установ на території Туреччини активісти кримських громад намагалися усіляко посприяти їхній діяльності ${ }^{41}$, запрошували українських дипломатів на власні заходи та свята тощо, сприяли зв'язкам громадян України 3 місією ${ }^{42}$. Згадки про це можна знайти в усіх без винятку друкованих виданнях кримських товариств ${ }^{43}$. Разом 3 цим, діаспора киримли вважала за свій обов'язок передати через дипломатів до української влади власне занепокоєння щодо проблемних питань їхнього народу у Криму, ситуації з правами та свободами репатріантів в Україні.

У відповідності до проукраїнської позиції Меджлісу, лідери Загального центру намагалися побудувати відносини з посольством України у Туреччині та Україною, задля чого у 1999 р. заснували Товариство турецько-української дружби, яке очолив голова ТКВКТ А.І. Киримли. Навіть, коли філія ТКВКТ в Істанбулі вирішила виразити протест проти ігнорування інтересів киримли у Криму, вони не стали влаштовувати публічну акцію протесту біля будівлі української дипломатичної місії, а звернулися з проханням до Генерального консульства України прийняти їх і висловили свою думку та вимоги у приміщенні дипломатичної місії ${ }^{44}$. Активісти кримської діаспори наголошували, що їхне завдання, щоб Україна сприймала Туреччину як союзника.

Натомість, довгі роки МЗС України не сприймало кримську громаду Туреччини, як власне діаспору України, і не намагалося використати фактор кримської громади Туреччини заради національних інтересів держави. Українські дипломати нехтували увагою активістів кримських товариств, а часом відношення до них було навіть просто ворожим.

\footnotetext{
${ }^{37}$ Вказ. інтерв'ю з Н.К. Баяром.

${ }^{38}$ Тогрул И. Турецко-крымские отношения в новых геополитических условиях (1991-2011) // Збірник доповідей і тез. III Міжнародний тюркологічний симпозіум «Минуле-теперішнє-майбутнє кримських татар» (15-17 жовтня 2012 р., Сімферополь - Крим / Україна). Сімферополь: Кримнавчпеддержвидав, 2014. С. 239.

${ }^{39}$ MÜSAN'in «Türk cumhuriyetleri ve Kırım Türkleri» konulu paneli // Emel. 1992. № 189. S. 36.

${ }^{40}$ Eskişehir Kırımın Sudak şehri ile kardeș şehir oldu // Kırım Postası. 1998. Sayı 2. S. 11.

${ }^{41}$ Інтерв'ю 3 Джелялом Ічтеном (Celâl İçten) записане 15.01 .2019 р. у м. Істанбул.

${ }^{42}$ Ibidem.

${ }^{43}$ Ukrayna Büyükelçisi konuğumuz oldu // Kırım Postası. 2000. Sayı 10. S. 5.

${ }^{44}$ Aydın F.T. Op. cit. P. 345.
} 
Часто-густо контакти 3 кримською діаспорою обмежувалися тільки питаннями оформлення віз до України ${ }^{45}$.

Багаторічне служіння А.І. Киримли власному народові $з$ гідністю оцінено народом киримли та світовою кримською діаспорою. Визнанням заслуг Киримли на Батьківщині, у Криму, стале присвоєння у 2000 р. звання почесного доктора Кримського інженернопедагогічного університету ${ }^{46}$. Його ювілеї також урочисто відзначали у Криму ${ }^{47}$. Ще за життя, на його честь у 2010 р. ТКВКТ разом з Фондом «Крим» заснував щорічний «Літературний конкурс імені Амєта Іхсана Киримли» для промоції рідної мови, в якому беруть участь юні та молоді кримці з усього світу ${ }^{48}$. За ініціативою автора, як голови Київського товариства кримських татар, Указом Президента України №263/2004 від 2 березня 2004 р. «за вагомий особистий внесок у розвиток співробітництва України та Турецької Республіки у гуманітарній сфері, надання практичної допомоги в облаштуванні кримських татар в Україні» А.І. Киримли був нагороджений орденом «За заслуги» III ступеня ${ }^{49}$, який йому вручив Голова Верховної Ради України В.М. Литвин під час візиту до Анкари. Знаменно, що лідер кримської діаспори став першим турецьким громадянином, який був відзначений українською державною нагородою ${ }^{50}$. Громадські центри Істанбульської філії ТКВКТ і ТКВКТ в Анкарі, де проходять більшість культурних, освітніх, мистецьких заходів кримців, також отримали ім'я А.І. Киримли.

A.I. Киримли користувався серед діаспорян беззаперечним авторитетом і повагою. За національною традицією усі шанобливо зверталися до нього не офіційно «пан», а Амєт-емджє $\epsilon^{51}$. Загалом, А.І. Киримли протягом 24 років був головою кримських об’єднань: 3 роки як голова кримського товариства Анкари та 21 рік як голова Загального центру об'єднання кримських товариств Туреччини.

A.I. Киримли помер 11 грудня 2011 р. в Анкарі. Співчуття з приводу його кончини виразили Президент України В.Ф. Янукович і Президент Турецької Республіки А. Гюль. Вшановуючи пам'ять видатного діяча кримської діаспори, церемонію похорону відвідали міністр закордонних справ А. Давудоглу та міністр культури та туризму Е. Гюнай, Голова Меджлісу кримськотатарського народу М. Джемілєв, Голова Партії націоналістичного руху Д. Бахчелі, численні представники кримських громад Криму, Туреччини, Румунії тощ $0^{52}$.

Справу життя А.І. Киримли продовжує його син - відомий турецький історик, професор Хакан Киримли, який вже сам є авторитетним діячем кримської діаспори Туреччини, та, справедливо, є сьогодні одним з облич сучасної діаспори.

\footnotetext{
${ }^{45}$ Вказ. інтерв'ю з Т. Калкаєм; вказ. інтерв'ю $з$ Дж. Ічтеном.

${ }^{46}$ Доктору Ахмету Ихсану Кырымлы - 90 лет! URL: https://avdet.org/ru/2010/04/19/doktoru-ahmetu-ihsanukyrymly-90-let/

${ }^{47}$ B Крыму широко отметят 85-летие главы крымскотатарской диаспоры Ахмета Кырымлы. URL: http://old.qha.com.ua/ru/obschestvo/v-krimu-shiroko-otmetyat-85letie-glavi-krimskotatarskoi-diaspori-turtsiiahmeta-kirimli/1272/

${ }^{48}$ Dr. Ahmet İhsan Kırımlı edebiyat ödülleri Kırım'da yapılan törenle verildi // Kırım Bülten. 2011. Sayı 70. S. 17-19.

${ }^{49}$ Про нагородження А. Киримли орденом «За заслуги». Указ Президента України № 263/2004 від 2 березня 2004 p. URL: https://www.president.gov.ua/documents/2632004-1523

${ }^{50}$ Ахмет Ихсан Кырымлы. URL: http://medeniye.org/node/815

${ }^{51}$ Етсе - дядько з боку батька, за національною традицією киримли вживається як ввічливе звернення до старших чоловіків.

${ }^{52}$ Dr. Ahmet İhsan Kırımlı'nın vefatı dolayısıyla // Kırım Bülten. 2011. Sayı 70. S. 2-4.
} 
Таким чином, досліджено, що діяльність видатного державного та громадського діяча Туреччини, Голови Товариства культури та взаємодопомоги кримських тюрків А.І. Киримли наприкінці 1980-х - початку 2000-х рр. була надзвичайно плідною та корисною. Встановлено, що саме А.І. Киримли, маючи виняткові лідерські й організаторські якості, сумів, подолавши розбіжності та протиріччя, об'єднати більш ніж два десятки різних організацій у загальнотурецьке товариство кримської діаспори, створити та розбудувати його розгалужену структуру. Його зусиллями об'єднання кримських громад стало потужною та впливовою організацією, з думкою якої змушені рахуватися як урядові органи, так і політичні сили країни.

Одним з головних досягнень А.І. Киримли є зміна напрямку діяльності діаспорних організацій, внаслідок чого був створений потужний рух підтримки репатріації народу киримли 3 місць колишнього заслання на історичну Батьківщину, вдалося вибудувати ефективну систему допомоги власному народові у поверненні до Криму, відродженню національної культури, причому як, власне, серед кримських громад, так і серед турецького суспільства загалом. Підтверджено, що важливість допомоги з боку кримської діаспори Туреччини у той період була критично важливою для процесів повернення й облаштування репатріантів, становлення національних інститутів киримли, відродження їхньої культури, освіти та духовності тощо. Також досліджені контакти А.І. Киримли зі світової українською діаспорою та його діяльність стосовно розвиткові плідних відносин між Україною та Туреччиною в якості голови Товариства турецько-української дружби. Встановлено, що роль А.І. Киримли в об’єднанні кримської діаспори Туреччини була вкрай важливою, а внесок у розвиток діаспорного руху - вирішальним.

\title{
Rustem Ablâtifov
}

\section{A Role of A.I. Kirımlı to Develop the Crimean Diaspora in Turkey (late 1980s - early 2000s)}

\begin{abstract}
This article is devoted to activities of the prominent figure of the global and Turkey's Crimean diaspora, statesmen and politician, Ahmet İhsan Kırımll (1920-2011) to unite Turkey's Crimean diaspora, to institutionalize the diaspora's movement, to create conditions for an effectual support for the repatriation process of the Qiriml nation from the former places of the exile to their historical Motherland - Crimea by the Crimean associations of Turkey at the end of 20 century. His role and contribution to processes to restore the Qiriml's rights and freedoms, to revive their culture, language and education have been evaluated too. Also it have been studied little known in Ukraine historical facts on A.I. Kurımlis cooperation with the World Ukrainian diaspora and his activities to develop fruitful relations between the independent Ukraine and the Turkish Republic. Using his hugh prestige of the former lawmaker and minister, he managed to unite various associations and establish the powerful and influential umbrella organization of the Crimean centres in Turkey at the end of the 1980s. However, the principal accomplishment of A.I. Kirıml, as the Chairman of the General Centre of the Association of Culture and Mutual Aid of the Crimean Turks, in the first place, he re-
\end{abstract}


versed the direction of the Crimean associations' activity: not to meet their own needs and wishes, as to learn the folklore or conduct entertainments, but, to work for the sake the assistance for their own nation and the historical Motherland. Moreover, A.I. Kırıml made a significant contribution to develop the Turkish-Ukrainian relations as the head of the TurkishUkrainian friendship association. At the present time, the Association of Culture and Mutual Aid of the Crimean Turks is continuing to work based on the principles of A.I. Kirıml as a bridge between our countries.

Keywords: Ahmet İhsan Kırıml, Crimean diaspora, Qırıml, Crimea, Turkey, repatriation 